\title{
Risteytyksellä lisäarvoa ay-sonnin ruholle
}

\author{
Arto Huuskonen ${ }^{1)}$, Maiju Pesonen ${ }^{1)}$, Maarit Hyrkäs ${ }^{2)}$, Hilkka Kämäräinen ${ }^{3)}$ ja Risto Kauppinen ${ }^{3)}$ \\ ${ }^{1)}$ Maa-ja elintarviketalouden tutkimuskeskus, Kotieläintuotannon tutkimus, Tutkimusasemantie 15, \\ 92400 Ruukki, arto.huuskonen@mtt.fi,maiju.pesonen@mtt.fi \\ ${ }^{2)}$ Maa-ja elintarviketalouden tutkimuskeskus, Kotieläintuotannon tutkimus, Halolantie 31A, 71750 \\ Maaninka,maarit.hyrkas@mtt.fi \\ ${ }^{3)}$ Savonia-ammattikorkeakoulu, PL 72, 74101 Iisalmi, hilkka.kamarainen@savonia.fi, \\ risto.kauppinen@savonia.fi
}

\section{Tiivistelmä}

Tutkimuksella selvitettiin risteytyseläinten lihantuotanto-ominaisuuksia puhtaisiin ayrshire-sonneihin (ay) verrattuna. Tutkimusaineistona käytettiin teurastamoilta saatua naudan ruhojen teurasaineistoa, johon yhdistettiin ProAgria Maatalouden Laskentakeskuksen kautta saatu eläimen emän rotutieto. Teurasaineiston analysoinnin lisäksi toteutettiin kasvatuskoe, jossa selvitettiin puhtaiden ay-sonnien rehun syöntiä ja hyväksikäyttöä ayxaberdeen angus, ayxlimousin ja ay×blonde d'Aquitaine-sonneihin verrattuna.

Teurasdatassa oli yhteensä 164812 havaintoa puhtaista ay-sonneista. Risteytyssonnien määrät datassa olivat seuraavat: 2329 ay $\times$ aberdeen angus (ay $\times a b), 1466$ ay $\times$ blonde d'Aquitaine (ay $\times b a), 1$ 044 ayxcharolais (ay $\times c h), 782$ ay $\times$ hereford (ayxhf), 5293 ayxlimousin (ayxli) ja 1270 ay $\times$ simmental (ay×si). Puhtailla ay-sonneilla keskimääräinen kasvatusaika oli aineistossa 592 vrk, nettokasvu 532 $\mathrm{g} / \mathrm{pv}$, teuraspaino $330 \mathrm{~kg}$, ruhojen lihakkuusluokka 4,7 (O-luokka) ja rasvaisuusluokka 2,4. Liharoturisteytysten käyttö paransi sonnien kasvua, lisäsi teuraspainoa ja paransi ruhojen lihakkuutta puhtaisiin ay-sonneihin verrattuna. Suurimmat teuraspainot ja korkeimmat nettokasvut saavutettiin ch-, si- ja baroduilla risteytettäessä. Ruhojen lihakkuus parani eniten (51-57\%) ba-, li- ja ch-rodun risteytyksiä käytettäessä.

Kasvatuskokeen sonnit olivat kokeen alkaessa noin kuuden kuukauden ikäisiä, ja ne teurastettiin 18 kuukauden iässä. Kokeen aikana sonnit saivat vapaasti seosrehua, joka sisälsi nurmisäilörehua ja litistettyä ohraa; molempia $50 \%$ seoksen kuiva-aineesta. Kokeessa käytetty säilörehu oli kohtuullisen hyvin sulavaa (D-arvo $672 \mathrm{~g} / \mathrm{kg} \mathrm{ka}$ ) ja rajoitetusti käynyttä sekä säilönnälliseltä laadultaan hyvää. Sonnit söivät rehua keskimäärin $9,41 \mathrm{~kg} \mathrm{ka} / \mathrm{pv}$ kokeen aikana. Rotujen välillä ei ollut merkitseviä eroja rehun syöntimäärissä. Tällöin myöskään energian ja valkuaisen saanti ei eronnut eri rotuyhdistelmien välillä. Ay-, ay×ab-, ay×li- ja ay×ba-sonnien nettokasvut olivat kokeen aikana 708, 742, 765 ja 797 g/pv. Korkeammista kasvutuloksista johtuen rehun hyväksikäyttö kasvuun oli liharoturisteytyksillä puhtaita ay-sonneja tehokkaampaa.

Liharoturisteytysten paremmat teurasominaisuudet näkyivät tuottajan saamassa tilityshinnassa. Laskelmien perusteella blonde d'Aquitaine-, charolais-, limousin- ja simmental-risteytyksillä eläinkohtainen teurastili oli 19-23\% suurempi puhtaisiin ay-sonneihin verrattuna. Aberdeen angus- ja hereford-risteytyksillä teuraspaino ja ruhojen lihakkuus olivat suuria rotuja matalammat, joten myös tilityshinta jäi matalammalle tasolle ollen kuitenkin 11-12\% parempi kuin puhtaalla ay-sonnilla. Koska kasvatuskokeen perusteella rehujen syönnissä ei ole merkitseviä eroja rotuyhdistelmien välillä, erot teurastilityksessä kuvaavat hyvin rotujen välistä taloudellista eroa loppukasvattajan kannalta.

Asiasanat: naudanlihantuotanto, sonnit, rodut, risteytykset, kasvu, syönti, ruhon laatu 


\section{Johdanto}

Liharotusiemennysten käyttömäärä suomalaisilla maitotiloilla on suositeltu pidettävän 10-20 prosentin tasolla. Käytännössä toteutuma on kuitenkin ollut viime vuosina vain noin 5-6 prosentin luokkaa. Liharotusiemennysten osuus voitaisiin kuitenkin uusia tekniikoita (genominen valinta, siittiöiden sukupuolilajittelu) hyödyntäen nostaa ainakin 25 prosenttiin siemennyksistä. Toimenpiteellä voitaisiin tehostaa lehmävalintaa ja edistää eläinaineksen paranemista maidontuotannossa. Samalla olisi mahdollista lisätä naudanlihantuotannon tehokkuutta risteytysvasikoiden kautta. Viimeisen 25 vuoden aikana Suomessa ei ole tehty kasvatuskokeita eläinaineksella, joka pohjautuisi lypsylehmien ja liharotuisten sonnien jälkeläisiin. Naudanlihantuotannon edistämisprojektin aineistot 1990-luvulla perustuivat hereford-ayrshire ja limousin-ayrshire -rotuisiin emolehmiin ja niiden jälkeläisten kasvatuskokeisiin (Manninen ym. 1994). Ulkomaisissa tutkimuksissa liharoturisteytysten on todettu lisäävän ruhon arvopalojen saantoa (Keane ym. 1989), teurasprosenttia (Güngör ym. 2003) ja lihantuotannon taloudellista arvoa (Wolfová ym. 2007) puhtaisiin maitorotuisiin eläimiin verrattuna. Savoniaammattikorkeakoulun hallinnoiman MAILI-hankkeen tavoitteena on lisätä liharotusiemennysten osuutta lypsykarjatiloilla. Hankkeen tutkimusosioissa selvitettiin maito-liharisteytyssonnien kasvu- ja teurasominaisuuksia laajan teurasaineiston kautta. Tämän lisäksi toteutettiin kasvatuskoe, jossa selvitettiin maito-liharisteytyssonnien rehun syöntiä suhteessa puhtaisiin ayrshire-sonneihin.

\section{Aineisto ja menetelmät Teurasdata ja leikkuusaannot}

Tutkimusaineistona oli teurastamoilta saatu naudan ruhojen teurasaineisto, johon yhdistettiin ProAgria Maatalouden Laskentakeskuksen kautta saadut rotutiedot. Teurastamoaineistoa oli käytössä Hk Agri Oy:Itä ja Snellman Lihanjalostus Oy:Itä vuodesta 2007 lähtien, A-Tuottajat Oy:ltä vuodesta 2008 lähtien ja Saarioinen Lihanjalostus Oy:Itä vuodesta 2010 lähtien. Yhdistetyssä datassa olivat mukana seuraavat tiedot: eläimen syntymätunnus, teurastuspäivä, teuraspaino, teurastuksessa hylättyjen osien paino, ruhon laatuluokka, ruhon rasvaisuusluokka, eläimen syntymäaika, eläimen sukupuoli, eläimen rotukoodi, eläimen emän rotukoodi ja eläimen isän rotukoodi. Teurasruhot oli teurastamoissa punnittu ja luokiteltu EUROP - luokituksen mukaisesti (EC 2006). Nettokasvutulosten laskemiseksi dataan lisättiin uutena muuttujana eläimen lihapaino syntyessä (alkupaino). Tämä lisättiin oletusarvona siten, että alkupainoksi määritettiin sonnivasikalle $16 \mathrm{~kg}$ ja lehmävasikalle $15,2 \mathrm{~kg}$. Vastaavia arvioita ATuottajat Oy käyttää päivittäisessä työssään (Herva ym. 2009). Nettokasvu laskettiin teuraspainon ja kokeen alun lihapainon erotuksena jaettuna kasvatuspäivillä. Datan käsittelyn ensimmäisessä vaiheessa teurasaineistosta valittiin sonnit, jotka olivat rodultaan puhtaita ayrshirejä (sekä emä että isä luokiteltu ay-rotuiseksi) tai ay-emän ja liharotuisen isän jälkeläisiä. Alle 12 kk:n (alle 365 pv) ja yli 24 kk:n (yli 730 pv) ikäisenä teurastetut eläimet rajattiin pois. Puhtaita ay-rotuisia sonneja jäi lopulliseen dataaineistoon yhteensä $164812 \mathrm{kpl}$. Ayxliharoturisteytyssonneja lopullisessa aineistossa oli seuraavasti ayxaberdeen angus (ab) $2329 \mathrm{kpl}$, ay $\times$ hereford (hf) $782 \mathrm{kpl}$, ay $\times$ limousin (li) $5293 \mathrm{kpl}$, ay $\times$ charolais (ch) $1044 \mathrm{kpl}$, ayxsimmental (si) $1270 \mathrm{kpl} \mathrm{ja} \mathrm{ay \times blonde} \mathrm{d'Aquitaine} \mathrm{(ba)} 1466 \mathrm{kpl}$.

Laajemman teurasaineiston lisäksi laskettiin eläinten ruhojen arvopalojen (fileet ja paistit) saantoja Snellman Lihanjalostus Oy:n teurasaineiston pohjalta. Snellman Lihanjalostus Oy:llä syntyy eläinten teurastuksen yhteydessä tietokanta kaikkien ruhojen arvopalojen osuuksista kussakin teurasruhossa. Arvopalojen saannot laskettiin samoille rotuyhdistelmille kuin laajemman teurasaineiston muuttujat. Leikkuusaantoaineistossa oli puhtaita ay-rotuisia sonneja yhteensä $16 \quad 037 \mathrm{kpl}$. Ay $\times$ liharoturisteytyssonneja oli leikkuusaantoaineistossa seuraavasti ay $\times a b 176 \mathrm{kpl}$, ay $\times \mathrm{hf} 45 \mathrm{kpl}$, ayxli $287 \mathrm{kpl}$, ay $\times \mathrm{ch} 49 \mathrm{kpl}$, ayxsi $105 \mathrm{kpl} \mathrm{ja}$ ay×ba $128 \mathrm{kpl}$.

Tilastollisena käsittelynä tuloksille tehtiin varianssianalyysi SAS 9.2. -ohjelmiston MIXEDproseduurilla. Rotujen välisten erojen tilastollinen merkitsevyys testattiin pareittaisilla vertailuilla Dunnetin -testillä. Testillä vertailtiin puhtaiden ay-sonnien tuloksia erikseen kuhunkin ay $\times$ liharotusonnien tuloksiin.

\section{Kasvatuskoe}

Kasvatuskoe suoritettiin MTT:n Siikajoen toimipisteessä. Koe alkoi tammikuussa 2011 ja siihen valittiin kolme tällä hetkellä yleisintä liharoturisteytystä: Ay $\times \mathrm{Ab}, \mathrm{Ay} \times \mathrm{Li}$ ja Ay $\times \mathrm{Ba}$. Vertailuryhmänä kokeessa olivat puhtaat ay-sonnit. Kussakin roturyhmässä oli 9 eläintä, jotka hankittiin A-Tuottajat Oy:n eläinvälityksestä. Sonnit olivat kokeen alkaessa noin kuuden kuukauden ikäisiä, ja ne teurastettiin 
keskimäärin 18 kuukauden iässä. Sonnit kasvatettiin parsinavetassa, jolloin saatiin eläinkohtaisia havaintoja.

Kokeen aikana kaikkien koeryhmien sonnit saivat vapaasti seosrehua, joka sisälsi nurmisäilörehua ja litistettyä ohraa; molempia $50 \%$ seoksen kuiva-aineesta laskettuna. Valkuaislisä (rapsirouhetta $500 \mathrm{~g} /$ eläin / päivä) sekoitettiin kaikille kokeen sonneille käsin kunkin sonnin seosrehuannokseen. Kaikki eläimet saivat lisäksi kivennäisseosta (Seleeni Hertta Muro, Suomen Rehu Oy) ja vitamiinivalmistetta (Xylitol ADESAN, Suomen Rehu Oy). Kivennäisseos lisättiin seosrehuun käsin päivittäin ja vitamiinit kerran viikossa. Seosrehua tehtäessä säilörehusta otettiin näytteitä, jotka pakastettiin ja yhdistettiin jokaisen neljän viikon ruokintajakson analyysinäytteeksi. Ohrasta ja valkuaistiivisteestä kerättiin näytteet jokaisesta rehuerästä ja yhdistettiin eräkohtaisiksi analyysinäytteiksi. Säilörehuista ja väkirehuista analysoitiin kuiva-aine, tuhka, raakavalkuainen, neutraalidetergenttikuitu (NDF), raakarasva ja tärkkelys MTT:n laboratoriossa Jokioisilla Huuskosen (2011) kuvaamalla tavalla. Säilörehujen käymislaatu ( $\mathrm{pH}$, liukoinen typpi, ammoniumtyppi, vesiliukoiset hiilihydraatit, haihtuvat rasvahapot ja maito- sekä muurahaishappo) määritettiin Valio Oy:ssä käytössä olevalla puristenestetitraukseen pohjautuvalla laatumäärityksellä (Moisio ja Heikonen 1989). Säilörehun D-arvo (sulavan orgaanisen aineen pitoisuus kuiva-aineessa) määritettiin Huhtasen ym. (2006) mukaisesti. Rehujen energia- ja valkuaisarvot laskettiin MTT:n (2012) kuvaamalla tavalla.

Kokeessa käytetty säilörehu oli kohtuullisen hyvin sulavaa (D-arvo $672 \mathrm{~g} / \mathrm{kg} \mathrm{ka}$ ) ja rajoitetusti käynyttä sekä säilönnälliseltä laadultaan hyvää (Taulukko 1). Sonnien saama seosrehu sisälsi energiaa 11,8 MJ/kg ka, raakavalkuaista $160 \mathrm{~g} / \mathrm{kg}$ ka ja seoksen PVT-arvo oli $22 \mathrm{~g} / \mathrm{kg}$ ka. Yksityiskohtaiset tiedot rehujen ja seosrehun koostumuksesta ja rehuarvoista esitetään taulukossa 1.

Taulukko 1. Kokeessa käytettyjen rehujen sekä seosrehun kemialliset koostumukset ja rehuarvot.

\begin{tabular}{lcccc}
\hline & Säilörehu & Ohra & Rypsi & Seosrehu \\
\hline Kuiva-aine (KA), g/kg & 355 & 894 & 881 & 508 \\
Orgaaninen aine, g/kg KA & 930 & 975 & 927 & 949 \\
Raakavalkuainen, g/kg KA & 157 & 132 & 341 & 160 \\
NDF, g/kg KA & 540 & 241 & 331 & 397 \\
Raakarasva, g/kg KA & 37 & 16 & 30 & 28 \\
Tärkkelys, g/kg KA & 1 & 524 & 30 & 230 \\
Muuntokelpoinen energia, MJ/kg KA & 10,7 & 13,1 & 11,7 & 11,8 \\
OIV, g/kg KA & 82 & 98 & 151 & 94 \\
PVT, g/kg KA & 35 & -16 & 111 & 22 \\
D-arvo & 669 & & & \\
Säilörehun säilönnällinen laatu & & & & \\
pH & 4,57 & & & \\
Haihtuvat rasvahapot, g/kg KA & 16 & & & \\
Maito- ja muurahaishappo, g/kg KA & 28 & & & \\
Sokeri, g/kg KA & 98 & & & \\
Kokonaistypestä, g/kg & & & & \\
$\quad$ NH ${ }_{4} N$ & 61 & & & \\
Liukoinen typpi & 465 & & &
\end{tabular}

Sonnit teurastettiin kahdessa erässä Atria Oy:n Kauhajoen teurastamossa. Sonnien päiväkasvu laskettiin loppupainon ja kokeen alun painon erotuksena jaettuna kasvatuspäivillä. Nettokasvu laskettiin teuraspainon ja kokeen alun ruhopainon erotuksena jaettuna kasvatuspäivillä. Ruhopainona kokeen alussa käytettiin elopaino $\times 0,5$. Teurastus tapahtui yleisten teurastuskäytäntöjen mukaan ja ruhot luokiteltiin EUROP-luokituksella (EC 2006).

Tulosten tilastollisena käsittelynä tehtiin varianssianalyysi SAS-ohjelmiston GLMproseduurilla. Testauksessa käytetty koe-malli oli: $\mathrm{y}_{\mathrm{ijk}}=\mu+\beta_{\mathrm{j}}+\alpha_{\mathrm{i}}+\mathrm{e}_{\mathrm{ijk}}$, missä $\mu$ on yleiskeskiarvo, $\alpha_{\mathrm{i}}$ on koekäsittelyn (rotu) kiinteä vaikutus (i=1,2,3,4), $\beta_{\mathrm{j}}$ on teuraserän satunnaisvaikutus $(\mathrm{k}=1,2) \mathrm{ja} \mathrm{e}_{\mathrm{ijk}}$ on virhetermi. Rotujen välisten erojen tilastollinen merkitsevyys testattiin pareittaisilla vertailuilla Dunnetin -testillä. Testillä vertailtiin puhtaiden ay-sonnien tuloksia erikseen kuhunkin ayxliharotusonnien tuloksiin. 


\section{Tulokset ja tulosten tarkastelu Teurasdata ja leikkuusaannot}

Teurasaineiston perusteella limousin on tällä hetkellä ylivoimaisesti eniten käytetty rotu maitotilojen liharotusiemennyksissä. Aineiston liharoturisteytyksistä $43 \%$ oli limousin-risteytyksiä. Seuraavaksi eniten oli käytetty aberdeen angus (19\%) ja blonde d'Aquitaine (12\%) rotuja. Charolais- ja simmental-risteytyksiä oli noin $10 \%$ aineiston eläimistä ja herefordeja $6 \%$.

Aineiston perusteella rotujen välillä on selkeitä eroja kasvu- ja teurasominaisuuksissa. Liharoturisteytysten käyttö paransi sonnien kasvua, lisäsi teuraspainoa ja paransi ruhojen lihakkuutta (Taulukko 2). Kaikilla testatuilla liharoturisteytyksillä oli positiivinen vaikutus edellä mainittuihin ominaisuuksiin. Suurimmat teuraspainot ja korkeimmat nettokasvut saavutettiin charolais-, simmental- ja blonde d'Aquitaine-roduilla risteytettäessä (Taulukko 2). Ruhojen lihakkuus parani eniten blonde d'Aquitaine-, limousin ja charolais-rodun risteytyksiä käytettäessä. Lihakkuus parani yli $50 \%$ puhtaaseen ay-sonniin verrattuna edellä mainittuja risteytyksiä käytettäessä. Simmental-risteytyksillä saavutettiin $36 \%$ parempi lihakkuus kuin puhtailla ay-sonneilla. Angus- ja hereford-risteytyksillä lihakkuus lisääntyi 23-28 \% puhtaisiin ay-sonneihin verrattuna.

Ruhon rasvaisuuden osalta risteyttäminen blonde d'Aquitaine-rodulla vähensi ruhojen rasvaisuutta puhtaisiin ay-sonneihin verrattuna. Sen sijaan muilla liharoduilla risteyttäminen näytti hieman lisäävän ruhojen rasvaisuutta puhtaisiin maitorodun eläimiin verrattuna. Sekä ruhojen lihakkuuden että rasvaisuuden osalta on kuitenkin huomioitava myös teuraspainon vaikutus, sillä teuraspainon nousu paransi ruhojen lihakkuutta ja lisäsi rasvaisuutta kaikilla testatuilla roduilla ja rotuyhdistelmillä. Samoin nettokasvun lisääntyminen paransi ruhojen lihakkuutta ja lisäsi rasvaisuutta kaikilla roduilla ja rotuyhdistelmillä.

Rotuyhdistelmien välillä oli selkeitä eroja myös lihasaannoissa (Taulukko 2). Risteyttäminen blonde d'Aquitaine-, charolais- ja limousin-roduilla lisäsi merkitsevästi $(p<0,001)$ sisäfileen, ulkofileen, sisäpaistin, ulkopaistin, kulmapaistin ja paahtopaistin prosentuaalisia saantoja puhtaaseen aysonniin verrattuna. Simmental-rodulla risteyttäminen lisäsi kaikkien muiden edellä mainittujen arvopalojen paitsi kulmapaistin prosentuaalista osuutta lihasaannosta. Hereford- ja aberdeen angusristeytyksillä vastaavia lisäyksiä arvopalojen saannoissa ei havaittu (Taulukko 2). Herefordristeytysten tulokset eivät poikenneet tilastollisesti merkitsevästi puhtaiden ay-sonnien tuloksista. Sen sijaan aberdeen angus-risteytyksillä sisäfileen, sisäpaistin ja kulmapaistin prosentuaaliset osuudet olivat jopa merkitsevästi pienemmät kuin puhtailla ay-sonneilla.

Myös kaupallisen leikkuun yhteydessä erotetun rasvan määrässä oli eroja rotujen välillä. Blonde d'Aquitaine-risteytyksillä rasvan prosentuaalinen osuus leikkuusaannosta oli merkitsevästi pienempi kuin puhtailla ay-sonneilla. Sen sijaan aberdeen angus-, hereford- ja simmental-risteytyksillä rasvan osuus oli suurempi kuin puhtailla ay-sonneilla. Charolais- ja limousin-risteytykset eivät eronneet merkitsevästi puhtaista ay-sonneista ruhon rasvasaannon osalta (Taulukko 2).

Koska liiketoiminnan järkevyyden ratkaisee viime kädessä taloudellinen tulos, hankkeessa selvitettiin myös eri rotuyhdistelmille maksettavat laskennalliset teurastilitykset. Samoin kuin kasvu- ja teurastulokset myös lasketut teurastilitykset kuvaavat aineiston keskimääräisen eläimen saavuttamaa tulosta. Tilityshinnat laskettiin A-Tuottajien sopimustuottajahinnaston mukaan. Kaikilla liharoturisteytyksillä saatiin selkeästi suuremmat eläinkohtaiset teurastilit puhtaisiin maitorotuisiin eläimiin verrattuna. Korkeammista teuraspainoista ja paremmasta lihakkuudesta johtuen isoilla liharoduilla saavutettiin parhaat tilityshinnat. Ch-, ba-, li- ja si-risteytyksillä eläinkohtainen teurastili oli 19-23\% suurempi puhtaisiin ay-sonneihin verrattuna. Keskikokoisilla liharoduilla ( $\mathrm{ab}$ ja hf) teuraspaino ja ruhojen lihakkuus olivat suuria rotuja matalammat, joten myös tilityshinta jäi matalammalle tasolle ollen kuitenkin 11-12 \% suurempi kuin puhtaalla ay-sonnilla. Koska kasvatuskokeen perusteella rehujen syönnissä ei ollut merkitseviä eroja rotuyhdistelmien välillä, saadut erot teurastilityksessä kuvaavat melko hyvin rotujen välistä taloudellista eroa loppukasvattajan kannalta.

\section{Kasvatuskoe}

Koesonnien rehun syönti sekä kasvu- ja teurastulokset on esitetty taulukossa 3. Sonnit söivät rehua keskimäärin 9,41 kg ka/pv kokeen aikana. Ryhmien välillä ei ollut merkitseviä eroja rehun syöntimäärissä. Tällöin myöskään energian ja valkuaisen saanti ei eronnut eri rotuyhdistelmien välillä. 
Taulukko 2. Puhtaiden ayrshiresonnien (ay) sekä ay $\times$ liharoturisteytyssonnien kasvu- ja teurastulokset valtakunnallisessa teurasaineistossa sekä lihasaannot Snellman Lihanjalostus Oy:n aineistossa roduittain $(\mathrm{ab}=$ aberdeen angus, $\mathrm{ba}=$ blonde d'Aquitaine, $\mathrm{ch}=$ charolais, $\mathrm{hf}=$ hereford, li $=$ limousin, $\mathrm{si}=\mathrm{simmental})$.

\begin{tabular}{|c|c|c|c|c|c|c|c|c|c|c|c|c|c|c|c|}
\hline & \multicolumn{7}{|c|}{ Rotu } & \multirow[b]{2}{*}{ SEM $^{1}$} & \multicolumn{7}{|c|}{ Tilastollinen merkitsevyys $^{2}$} \\
\hline & ayxay & ayxab & ayxba & ay $\times$ ch & ay $\times$ hf & ay $\times$ li & ay $\times$ si & & $\mathrm{p}$-arvo & ayxab & ay $\times$ ba & ay $\times$ ch & ay $\times$ hf & ay $\times$ li & ay $\times$ si \\
\hline \multicolumn{16}{|c|}{ Valtakunnallinen teurasaineisto } \\
\hline Eläinmäärä, kpl & 164812 & 2329 & 1466 & 1044 & 782 & 5293 & 1270 & & & & & & & & \\
\hline Kasvatusaika, pv & 592 & 596 & 583 & 586 & 588 & 590 & 583 & 2,2 & $<0,001$ & $*$ & $* * *$ & $*$ & & & $* * *$ \\
\hline Nettokasvu, g/pv & 532 & 576 & 616 & 629 & 580 & 605 & 628 & 2,8 & $<0,001$ & $* * *$ & $* * *$ & $* * *$ & $* * *$ & $* * *$ & $* * *$ \\
\hline Teuraspaino, kg & 330 & 357 & 374 & 383 & 356 & 372 & 381 & 1,7 & $<0,001$ & $* * *$ & $* * *$ & $* * *$ & $* * *$ & $* * *$ & $* * *$ \\
\hline Lihakkuus $^{3}$ & 4,7 & 6,0 & 7,4 & 7,1 & 5,8 & 7,3 & 6,4 & 0,04 & $<0,001$ & $* * *$ & $* * *$ & $* * *$ & $* * *$ & $* * *$ & $* * *$ \\
\hline Rasvaisuus $^{4}$ & 2,4 & 3,1 & 2,2 & 2,5 & 3,2 & 2,6 & 2,7 & 0,02 & $<0,001$ & $* * *$ & $* * *$ & $* * *$ & $* * *$ & $* * *$ & $* * *$ \\
\hline \multicolumn{16}{|c|}{ Snellman Lihanjalostus Oy:n aineisto } \\
\hline Eläinmäärä, kpl & 16037 & 176 & 128 & 45 & 49 & 287 & 105 & & & & & & & & \\
\hline Kasvatusaika, pv & 592 & 597 & 568 & 597 & 582 & 592 & 571 & 10,0 & $<0,001$ & & $* * *$ & & & & $* *$ \\
\hline Teuraspaino, kg & 318 & 339 & 362 & 366 & 330 & 353 & 360 & 7,2 & $<0,001$ & $* * *$ & $* * *$ & $* * *$ & & $* * *$ & $* * *$ \\
\hline Lihakkuus $^{3}$ & 4,8 & 5,9 & 7,2 & 7,2 & 5,4 & 7,2 & 6,0 & 0,13 & $<0,001$ & $* * *$ & $* * *$ & $* * *$ & $* * *$ & $* * *$ & $* * *$ \\
\hline Rasvaisuus $^{4}$ & 2,5 & 3,1 & 2,4 & 2,6 & 3,1 & 2,7 & 2,8 & 0,10 & $<0,001$ & $* * *$ & & & $* * *$ & $* * *$ & $* * *$ \\
\hline \multicolumn{16}{|c|}{ Lihasaannot, \% kokonaissaannosta } \\
\hline Rasva & 4,73 & 6,28 & 3,79 & 4,37 & 5,48 & 4,60 & 5,25 & 0,222 & $<0,001$ & $* * *$ & $* * *$ & & $* *$ & & $* *$ \\
\hline Ulkofile & 3,79 & 3,73 & 4,31 & 4,13 & 3,70 & 4,26 & 3,98 & 0,050 & $<0,001$ & & $* * *$ & $* * *$ & & $* * *$ & $* * *$ \\
\hline Sisäfile & 1,36 & 1,33 & 1,50 & 1,46 & 1,34 & 1,44 & 1,44 & 0,020 & $<0,001$ & $*$ & $* * *$ & $* * *$ & & $* * *$ & $* * *$ \\
\hline Sisäpaisti & 3,61 & 3,55 & 4,03 & 3,84 & 3,51 & 4,08 & 3,75 & 0,051 & $<0,001$ & $*$ & $* * *$ & $* * *$ & & $* * *$ & $* * *$ \\
\hline Ulkopaisti & 5,66 & 5,73 & 6,48 & 6,32 & 5,76 & 6,43 & 6,03 & 0,073 & $<0,001$ & & $* * *$ & $* * *$ & & $* * *$ & $* * *$ \\
\hline Kulmapaisti & 3,40 & 3,29 & 3,61 & 3,57 & 3,31 & 3,59 & 3,36 & 0,042 & $<0,001$ & $* * *$ & $* * *$ & $* * *$ & & $* * *$ & \\
\hline Paahtopaisti & 1,67 & 1,69 & 1,94 & 1,87 & 1,66 & 1,87 & 1,82 & 0,027 & $<0,001$ & & $* * *$ & $* * *$ & & $* * *$ & $* * *$ \\
\hline
\end{tabular}

SEM = Keskiarvon keskivirhe.

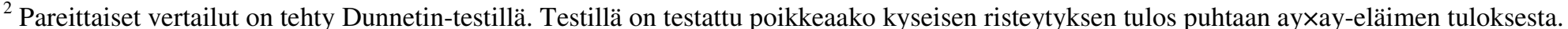

$* * *(\mathrm{p}<0,001), * *(\mathrm{p}<0,01), *(\mathrm{p}<0,05)$ ja o $(\mathrm{p}<0,10)$.

${ }^{3}$ Lihakkuus: EUROP-luokitus $(1=$ heikoin, $15=$ paras $) .1=\mathrm{P}-, 2=\mathrm{P}, 3=\mathrm{P}+, 4=\mathrm{O}-, 5=\mathrm{O}, 6=\mathrm{O}+, 7=\mathrm{R}-, 8=\mathrm{R}, 9=\mathrm{R}+, 10=\mathrm{U}-, 11=\mathrm{U}, 12=\mathrm{U}+, 13=\mathrm{E}-, 14=\mathrm{E}, 15=\mathrm{E}+$.

${ }^{4}$ Rasvaisuus: EUROP-luokitus ( 1 = rasvaton, 5 = erittäin rasvainen). 
Taulukko 3. Rodun vaikutus sonnien rehun syöntiin, kasvuun, rehun hyväksikäyttöön ja teurastuloksiin kasvatuskokeessa. $($ Ay $=$ ayrshire, $\mathrm{Ab}=$ aberdeen angus, Ba $=$ blonde d'Aquitaine, $\mathrm{Li}=$ limousin).

\begin{tabular}{|c|c|c|c|c|c|c|c|c|}
\hline & \multicolumn{4}{|c|}{ Rotu } & \multirow[b]{2}{*}{ SEM $^{1}$} & \multicolumn{3}{|c|}{ Tilastollinen merkitsevyys $^{2}$} \\
\hline & AyxAy & $\mathrm{Ay} \times \mathrm{Ab}$ & Ay $\times \mathrm{Li}$ & $\mathrm{Ay} \times \mathrm{Ba}$ & & $\mathrm{Ay} \times \mathrm{Ab}$ & Ay $\times \mathrm{Li}$ & $\mathrm{Ay} \times \mathrm{Ba}$ \\
\hline Eläinmäärä & 9 & 9 & 8 & 9 & & & & \\
\hline Ikä kokeen alussa, pv & 202 & 201 & 198 & 197 & 3,5 & & & \\
\hline Kokeen kesto, pv & 359 & 354 & 363 & 355 & 12,2 & & & \\
\hline \multicolumn{9}{|l|}{ Rehun syönti ja ravintoaineiden saanti } \\
\hline Syönti, kg KA/pv & 9,41 & 9,56 & 9,21 & 9,43 & 0,224 & & & \\
\hline Muuntokelpoinen energia, $\mathrm{MJ} / \mathrm{pv}$ & 111,7 & 113,7 & 109,6 & 112,1 & 2,63 & & & \\
\hline Raakavalkuainen, g/pv & 1464 & 1489 & 1435 & 1469 & 38,0 & & & \\
\hline $\mathrm{NDF}, \mathrm{g} / \mathrm{pv}$ & 5148 & 5224 & 5030 & 5158 & 124,6 & & & \\
\hline Alkupaino, kg & 224 & 239 & 226 & 236 & 10,8 & & & \\
\hline Loppupaino, kg & 685 & 697 & 696 & 703 & 11,0 & & & \\
\hline Päiväkasvu, g/pv & 1298 & 1303 & 1313 & 1330 & 50,8 & & & \\
\hline Nettokasvu, g/pv & 708 & 742 & 765 & 797 & 27,1 & & o & $*$ \\
\hline \multicolumn{9}{|l|}{ Rehun hyväksikäyttö } \\
\hline kg KA/päiväkasvu-kg & 7,36 & 7,10 & 7,19 & 7,32 & 0,305 & & & \\
\hline kg KA/nettokasvu-kg & 13,51 & 12,48 & 12,38 & 12,19 & 0,583 & & & o \\
\hline MJ/päiväkasvu-kg & 87,5 & 84,5 & 85,4 & 87,0 & 3,61 & & & \\
\hline MJ/nettokasvu-kg & 160,5 & 148,4 & 147,2 & 144,8 & 6,49 & & & o \\
\hline \multicolumn{9}{|l|}{ Teurastulokset } \\
\hline Teuraspaino, kg & 364 & 381 & 387 & 398 & 7,3 & o & $*$ & $* *$ \\
\hline Teurasprosentti, g/kg & 531 & 546 & 556 & 567 & 7,8 & & $*$ & $* *$ \\
\hline Lihakkuus ${ }^{3}$ & 5,7 & 6,7 & 7,9 & 8,1 & 0,42 & 0 & $* * *$ & $* * *$ \\
\hline Rasvaisuus ${ }^{4}$ & 3,1 & 4,3 & 3,5 & 3,0 & 0,14 & $* * *$ & $*$ & \\
\hline
\end{tabular}

SEM = Keskiarvon keskivirhe.

${ }^{2}$ Pareittaiset vertailut on tehty Dunnetin-testillä. Testillä on testattu poikkeaako kyseisen risteytyksen tulos puhtaan ay $\times$ ay-eläimen tuloksesta.

$* * *(\mathrm{p}<0,001), * *(\mathrm{p}<0,01), *(\mathrm{p}<0,05)$ ja o $(\mathrm{p}<0,10)$

${ }^{3}$ Lihakkuus: EUROP-luokitus $(1=$ heikoin, 15 = paras). 1=P-, 2=P, 3=P+, 4=O-, 5=O, 6=O+, 7=R-, 8=R, 9=R+, 10=U-, 11=U, 12=U+, 13=E-, 14=E, 15=E+.

${ }^{4}$ Rasvaisuus: EUROP-luokitus ( 1 = rasvaton, 5 = erittäin rasvainen) 
Ay-sonnien teuraspaino oli kokeessa keskimäärin $364 \mathrm{~kg}$ ja liharoturisteytykset kasvatettiin tätä hieman suurempiin teuraspainoihin. Teuraspainot olivat siten kokeessa jonkin verran valtakunnallisen teurasaineiston keskimääräisiä teuraspainoja suuremmat. Sonnien keskimääräinen päiväkasvu oli kokeen aikana $1311 \mathrm{~g} / \mathrm{pv}$ ja nettokasvu $753 \mathrm{~g} / \mathrm{pv}$. Päiväkasvutuloksissa ei ollut tilastollisesti merkitseviä eroja rotuyhdistelmien välillä, mutta nettokasvussa ba-risteytykset saavuttivat $12 \%$ puhtaita aysonneja paremman kasvutason ja li-risteytysten nettokasvu oli $8 \%$ ay-sonneja parempi. Korkeammista nettokasvutuloksista johtuen rehun hyväksikäyttö oli risteytyksillä puhtaita ay-sonneja tehokkaampaa.

Li- ja ba-risteytyksillä teurasprosentit olivat merkitsevästi korkeammat kuin puhtailla aysonneilla, mikä pääosin selittää nettokasvutuloksissa syntyneet erot. Ruhojen lihakkuuden osalta kaikki kokeessa mukana olleet risteytysvaihtoehdot paransivat ruhojen lihakkuutta puhtaisiin ay-sonneihin verrattuna. Parhaiten luokittuivat li- ja ba-risteytykset. Tulokset vastaavat teurasaineiston tuloksia, mutta lihakkuusluokat olivat tässä kokeessa kautta linjan korkeammat kuin teurasaineistossa, mikä selittynee pääosin suuremmilla teuraspainoilla. Myös ruhojen rasvaisuuden osalta tulokset olivat yhdenmukaiset teurasaineiston tuloksien kanssa. Osin suuremmasta teuraspainosta johtuen ab- ja li-ruhot olivat rasvaisempia kuin puhtaiden ay-sonnien ruhot. Sen sijaan ba-risteytyksillä ruhojen rasvaisuus ei lisääntynyt puhtaisiin maitorotuisiin verrattuna korkeammasta teuraspainosta huolimatta.

\section{Yhteenveto ja johtopäätökset}

Liharotusiemennyksillä pystytään tuottamaan puhtaisiin ay-sonneihin verrattuna paremmin kasvavia ja luokittuvia lihanautoja. Aineiston perusteella limousin on tällä hetkellä eniten käytetty rotu maitotilojen liharotusiemennyksissä. Tämä on tulosten pohjalta varsin perusteltua, sillä limousin-risteytyksillä saavutetaan hyvät kasvutulokset ja ruhot luokittuvat hyvin. Myös blonde d'Aquitaine-rotu sopii erinomaisesti käytettäväksi maitotilojen liharotusiemennyksissä, sillä se on aineiston perusteella selkeästi vähiten rasvoittuva rotu ja myös kasvu- ja lihakkuusominaisuudet ovat risteytyskäytössä hyvät. Niin ikään charolais- ja simmental-risteytysten kasvu- ja teurasominaisuudet osoittautuivat aineistossa hyviksi. Keskikokoisten liharotujen (ab, hf) risteytyksiä käytettäessä kasvu- ja teurastulokset jäivät selvästi pääteroturisteytyksiä (ba, ch, li, si) matalammalle tasolle. Naudanlihantuotannon kannalta katsottuna maitotiloilla käytettävien liharoturisteytysten lisäämisen tavoitteena tulisi olla nimenomaan naudanlihantuotannon tehokkuuden ja tuotettavan naudanlihamäärän lisääminen risteytysvasikoiden kautta. Näin ollen juuri pääterotujen käyttö maitotilojen liharotusiemennyksissä on suositeltavaa. Näiden rotujen risteytysvasikoilla voidaan pyrkiä korkeisiin teuraspainoihin yleensä ilman merkittävää riskiä ruhojen rasvoittumisesta ja samalla ruhoille saavutetaan hyvä lihakkuusluokka.

\section{Kirjallisuus}

EC 2006. Council Regulation (EC) No 1183/2006 of 24 July 2006 concerning the Community scale for the classification of carcasses of adult bovine animals. The Official Journal of the European Union L, 214: 1-6.

Güngör, M., Alçiçek, A. \& Önenç, A. 2003. Feedlot performance and slaughter traits of Friesian, Piemontese $\times$ Friesian and Limousin $\times$ Friesian young bulls under intensive beef production system in Turkey. J. Appl. Anim. Res. 24: 129-136.

Herva, T., Virtala, A-M., Huuskonen, A., Saatkamp, H. W. \& Peltoniemi, O. 2009. On-farm welfare and estimated daily carcass gain of slaughtered bulls. Acta Agric. Scand. Sect. A Anim. Sci. 59: 104-120.

Huhtanen, P., Nousiainen, J. \& Rinne, M. 2006. Recent developments in forage evaluation with special reference to practical applications. Agric. Food Sci. 15: 293-323.

Huuskonen, A. 2011. Effects of barley grain compared to commercial concentrate or rapeseed meal supplementation on performance of growing dairy bulls offered grass silage-based diet. Agric. Food Sci. 20: 191-205.

Keane, M. G., More O'Ferrall, G. J. \& Connolly, J. 1989. Growth and carcass composition of Friesian, Limousin $\times$ Friesian and Blonde d'Aquitaine $\times$ Friesian steers. Anim. Prod. 48: 353-365.

Manninen, M., Huhta, H., Virkajärvi, P., Joki-Tokola, E., Suvitie, M., Puntila, M.-L. \& Röpelinen, A. 1994. Risteytyseläinten ruokinta- ja kasvatuskokeet sekä ruhon ja lihan laatu. Teoksessa: toim. Tarja Korhonen ja Minna Toivonen. Naudanlihantuotannon kehittäminen: Naudanlihantuotannon edistämisprojektin loppuraportti. Helsinki: Maa- ja metsätalousministeriö. s. 35-80.

Moisio, T. \& Heikonen, M. 1989. A titration method for silage assessment. Anim. Feed Sci. Technol. 22: 341353.

MTT. 2012. Rehutaulukot ja ruokintasuositukset. Maa- ja elintarviketalouden tutkimuskeskus. Verkkojulkaisu. Saatavissa internetistä: https://portal.mtt.fi/portal/page/portal/Rehutaulukot

Wolfová, J., Wolf, J., Kvapilik, J. \& Kica, J. 2007. Selection for profit in cattle: II. Economic weights for dairy and beef sires in crossbreeding systems. J. Dairy Sci. 90: 2456-2467. 